Науковий вісник НлтУ України
Scientific Bulletin of UNFU
https://nv.nltu.edu.ua
$\begin{gathered}\text { https://doi.org/10.15421/40290607 } \\ \text { Article received 20.06.2019 p. } \\ \text { Article accepted 27.06.2019 p. } \\ \text { УДк 630*531:228.7:582.475(477.42) }\end{gathered}$

О. В. Жуковський

Поліський філіал УкрНДІЛГА ім. Г. М. Висоџького, с. Довжик, Украӥна

\title{
ПАРАМЕТРИ КРОН ДЕРЕВ ЕКСПЕРИМЕНТАЛЬНИХ СОСНОВИХ КУЛЬТУР, СТВОРЕНИХ З РІЗНОЮ ГУСТОТОЮ У ЖИТОМИРСЬКОМУ ПОЛІССІ
}

\begin{abstract}
Дослідження проведено у Житомирському Поліссі на стаціонарному досліді № 1, закладеному у 1976 р. Проаналізовано деякі параметри крон дерев (площу проекції, діаметр і протяжність крон дерев), а також зімкнутість пологу насаджень сосни звичайної (Pinus sylvestris L.) різної густоти. Встановлено, що за густоти насадження 4000-1000 шт. га ${ }^{-1}$ середній діаметр крони становить 2,4-4,0 м, різниця значень цього показника змінюється у межах 9-40 \%. Підтверджено достовірну різницю між середніми діаметрами крон дерев однофакторним дисперсійним аналізом на 95\% довірчому рівні, де $F_{\phi}=7,82 \ldots 126,03$ $>F_{m(0,95)}=3,89$. Виявлено, що за густоти насаджень 4000-2000 шт. га $^{-1}$ форма крони $є$ овальною, тоді як за густоти насадження 1000 шт. га ${ }^{-1}$ - майже округлою. Встановлено, що середня проекція площ крон дерев за густоти насадження $4000 \mathrm{i}$ 1000 шт. га $^{-1}$ коливається у межах 5,5-6,1 i 10,6-13,1 м² , різниця між цими параметрами становить 42-58 \%. Достовірну різницю між величинами проекції площ крон дерев підтверджено однофакторним дисперсійним аналізом, де $F_{\phi}=8,0 \ldots 108,7>$ $F_{m(0,95)}=3,89$. Простежено, що середня протяжність крони за густоти насадження 4000 і 1000 шт. га ${ }^{-1}$ знаходиться у межах 4,1-5,1 і 5,1-8,1 м, різниця між цими величинами становить 2-43\%. Зроблено висновок про те, що густота впливає на середній діаметр, проекцію площ і протяжність крон дерев, тоді як впливу густоти на зімкнутість намету не виявлено.
\end{abstract}

Ключові слова: сосна звичайна; діаметр крони; площа проекції крони; протяжність крони; зімкнутість.

Вступ. Вирощування високопродуктивних і стійких штучних деревостанів передбачає застосування відповідного регламенту регулювання їхньої густоти. Відомо, що її можна задавати під час створення культур або підтримувати за допомогою доглядових рубань за лісом. Густота є одним із чинників, який визначає процес росту, розвитку, диференціації і зрідження насадження, терміни їх змикання, продуктивність, якість деревини, санітарний стан і стійкість деревостанів. Вивчення впливу густоти на деревостани розпочалося ще у період становлення лісового господарства, однак аж до 60-х років XX ст. не було спільної думки з цього питання. Результати досліджень відзначались суперечностями, а набутий досвід було неможливо узагальнити (Yunovidov, 1951). Для виявлення впливу густоти на різні таксаційні показники та взаємозв'язок між ними почали закладати різні експерименти. Проведені спостереження у молодняках підтвердили зв'язок між густотою і такими параметрами дерев, як: протяжність, об'єм і площа крони, зімкнутість крон та намету, повнота (Mikhailova \& Kalugina, 2012; Shparyk, 2012; Kuznetsov et al., 1986; Sevko \& Kotsan, 2012).

У роботі А. П. Юновідова виявлено, що із збільшенням густоти від 1130 до 36500 шт. га $^{-1}$ проекція пологу зростає від 5200 до $9800 \mathrm{~m}^{2} \cdot \mathrm{ra}^{-1}$, відповідно також зростає і зімкнутість пологу від 0,52 до 0,98 (Yunovidov, 1951). У культурах із зменшенням густоти від 173000 до 960 шт. га $^{-1}$ зімкнутість крони збільшується від 1,24 до 2,60 $\mathrm{m}^{2} \cdot \mathrm{M}^{-2}$ (Razin \& Rogozin, 2012). 3 проведених спостережень у соснових лісах на півночі Росії виявлено тісний зв'язок між кількістю мутовок на дереві і густотою насадження залежно від віку. Цей зв'язок у 15річних культурах з густотою 500-4500 шт. га $^{-1}$ становить 0,87-0,53 відповідно, у 40-річних (500-2000 шт. га $\left.^{-1}\right)-0,50-0,30$ та у 80-річних (500-1000 шт. га $\left.^{-1}\right)-$ 0,44-0,35. При цьому у віці від 10 до 30 років діаметр крони збільшується від 1,1 до 2,6 м² (Kuznetsov et al., 1986). В інших публікаціях зазначено, що у чистих 40річних соснових насадженнях із зменшенням густоти протяжність крони збільшується від 15 до 20 \% висоти стовбура (Sevko \& Kotsan, 2012). Подібні висновки зробили і вчені УкрНДІЛГА для соснових насаджень степової зони. Їхні результати свідчать, що із збільшенням густоти насадження зменшується проекція площ, середній діаметр, об'єм та протяжність крони (Tarnopilska, 2014).

Дослідники констатували, що на формування крони впливає також і крок насадження. Дослідженнями, які проведені у 100-річних соснових деревостанах Сумської обл., підтверджено залежність між кроком насадження і формою крони. У соснових культурах з кроком 0,75 м утворюється деформована крона - вздовж ряду до 25-42\%, тоді як 3 кроком насадження 1,50 м вона має правильну округлу форму. При цьому середня площа крони в обох кроках насадження є майже однаковою (Ryabokin, 1995).

Інформація про авторів:

Жуковський Олег Валерійович, наук. співробітник, лабораторія лісівництва. Email: zh_oleh2183@ukr.net; https://orcid.org/0000-0003-3351-9856

Цитування за ДСтУ: Жуковський О. В. Параметри крон дерев експериментальних соснових культур, створених з різною густотою у Житомирському Поліссі. Науковий вісник НлтУ України. 2019, т. 29, № 6. С. 36-39.

Citation APA: Zhukovskyi, O. V. (2019). The parameters of crown trees experimental pine plantations, which are created with various density in Zhytomir Polyssia. Scientific Bulletin of UNFU, 29(6), 36-39. https://doi.org/10.15421/40290607 
Також встановлено, що із збільшенням початкової густоти надалі відбувається інтенсивніший відпад дерев, а інтенсивність відпаду залежить від зімкнутості крон та намету і відносної повноти. Насамперед відпадають дерева 3 протяжністю крони менше ніж 10-12\% висоти стовбура. Дослідники стверджували, що внутрішньовидова конкуренція та боротьба за поживні речовини, воду і світло найбільше виражена у насадженнях 3 початковою густотою 700-200000 шт. ' га ${ }^{-1}$, тоді як за густоти менше від 700 шт. га $^{-1}$ ці взаємовідносини між деревами спостерігають тільки у період досягнення ними віку рубки головного користування (Razin \& Rogozin, 2012).

Дотепер існують тільки фрагментарні результати досліджень щодо стану середньовікових соснових деревостанів, створених з різною густотою у Поліссі Украіни. На це наукове питання можуть дати відповідь моніторингові спостереження на стаціонарних дослідах.

Метою досліджень є виявлення впливу початкової густоти на формування параметрів крон дерев сорокарічних соснових насаджень.

Об'єкти і методи дослідження. Дослідження проводили на стаціонарному досліді № 1 у Кримоцькому лісництві (квартал 51, виділ 15), ДП "Радомишльське ЛМГ" Житомирської обл. (географічні координати: 5055'04.34" північної широти, 29²4' $88.88^{\prime \prime}$ східної довготи). Стаціонарний дослід закладено 1976 р. у чистих виробничих культурах сосни звичайної (Pinus sylvestris L.), які було створено у 1972 р. Розміщення садивних місць $-1,5 \times 0,5$ м. Тип лісорослинних умов - свіжий субір, грунт - дерново-слабо-опідзолений піщаний, рельєф - рівнинний. Соснові культури на стаціонарному досліді розділили за густотою на 3 варіанти (секції № 1-4 -4000 шт. га ${ }^{-1}$, секції № 5-8 - 2000 шт. га $^{-1}$ і секції № 9-12 - 1000 шт. га ${ }^{-1}$ ) та за агротехнічними заходами на 4 варіанти (секції № 1, 5 і 9 - застосування гербіцидів, секції № 2, 6 і 10 - одночасне застосування гербіцидів та внесення мінеральних добрив, секції № 3, 7 і 11 - внесення мінеральних добрив та секції 4, 8 і 12 проведення механізованого догляду) (Golovchanskiy et al., 1976). Порівняння і аналіз параметрів крони дерев за густотою проводили окремо в межах кожного варіанта за агротехнічними заходами, оскільки виявити вплив цих заходів нам не вдалося та водночас, ми не хотіли порушувати задуму авторів досліду і використали їхню термінологію.

Пробні площі закладали згідно з СОУ 02.02-37476:2006 "Площі пробні лісовпорядні. Метод закладання" (SOU 02.02-37-476, 2006). Розмір пробної площі регламентували наявністю на ній не менше 100 дерев сосни звичайної. На пробних площах вимірювали такі таксаційні параметри дерев: висоту і висоту до першої живої гілки $\left(h_{\text {жс }}\right)$ за допомогою висотоміра ВКН-1 3 точністю до 0,1 м та радіуси крони $\left(R_{\kappa}\right)$ у чотирьох напрямках (Пн, Пд, Зх, Сх) за допомогою мірної стрічки 3 точністю до $10 \mathrm{~cm}$. Величини радіусів крон $\left(R_{\kappa}\right)$ лягли в основу для визначення діаметрів крон, площ проекції крон $\left(S_{\kappa}\right)$, зімкнутості пологу (площу крон/площу ділян$\kappa u)$ та протяжності крон $\left(L_{\kappa}\right)$ (висоту - висоту до першої живої гілки) (Anuchin, 1982; Ilkiv, 1997; Pasternak, 1990; Tsuryk, 2006). Отримані матеріали польових досліджень опрацювали 3 використанням методів матема- тичної статистики (Tsarenko et al., 2000) за допомогою програм Microsoft Excel.

Результати й обговорення. Дослідження показали, що на варіанті зі застосуванням гербіцидів за густоти насадження 4000 шт. га $^{-1}$ середній діаметр крони становить 2,4 м, за густоти насадження 2000 шт. га $^{-1}-3,0$ м і за густоти насадження 1000 шт. га $^{-1}-4,0$ м (рисунок, a). Загалом на цьому варіанті виявили, що крони розвиваються за густоти насаджень 4000 і 1000 шт. га $^{-1}$ в усіх напрямках майже однаково. Винятком $є$ насадження 3 густотою 2000 шт. га $^{-1}$, де крони формуються однобоко у напрямку Пд3х. На варіантах з одночасним застосуванням гербіцидів і внесенням мінеральних добрив крони розвиваються подібно між собою, але дещо відрізняються від описаного вище варіанта ( див. рисунок, б і в). Так, на обох варіантах за густоти насадження 4000 шт. га $^{-1}$ становили 2,5-2,7 м, за густоти насадження 2000 шт. $\cdot$ га $^{-1}$ середні діаметри крони - 2,9 м і за густоти насадження 1000 шт. га $^{-1}$ середні діаметри крони - 3,94,0 м відповідно. Форма крони на варіантах 3 густотою насаджень 4000 і 2000 шт. га ${ }^{-1} \epsilon$ овальною, тоді як за густоти насадження 1000 шт. га $^{-1} \epsilon$ майже округлою. На варіанті з проведенням механізованого догляду за густоти насадження 4000 шт. га $^{-1}$ середній діаметр крон становить 2,6 м, за густоти насадження 2000 шт. га $^{-1}$ 3,1 м і за густоти насадження 1000 шт. га $^{-1}-3,6$ м (див. рисунок, г). Крони за густоти 4000 шт. $\cdot^{-1}{ }^{-1}$ і 2000 шт. $\cdot$ га ${ }^{1}$ розвиваються однаково відносно сторін світу і є овальними, а за густоти насадження 1000 шт. га $^{-1}$ крони розвиваються однобоко і зміщені в напрямку південного заходу.

За однофакторним дисперсійним аналізом на $95 \%$ довірчому рівні достовірну різницю спостерігаємо між середніми величинами діаметрів крон усіх насаджень у межах варіантів, де $F_{\phi}=7,82 \ldots 126,03>F_{m(0,95)}=3,89$.

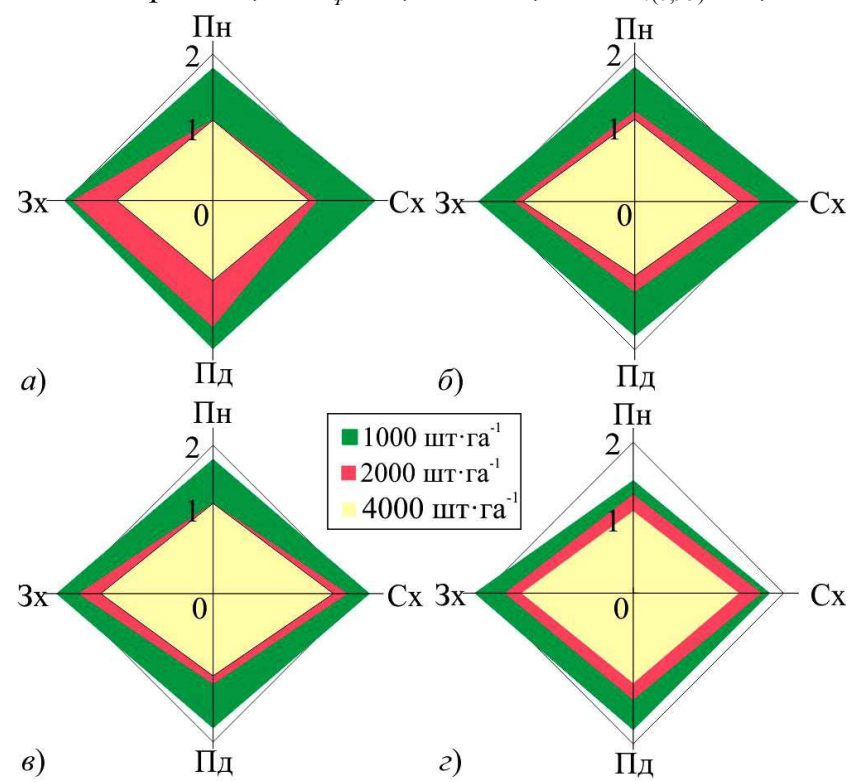

Рисунок. Середні діаметри крон соснових культур різної густоти на варіантах: $a$ - застосування гербіцидів; $\sigma$ - одночасне застосування гербіцидів та внесення мінеральних добрив; 8 - внесення мінеральних добрив; г - проведення механізованого догляду

Встановлення діаметрів крони дало змогу обрахувати середню площу проекції крони. Тенденція збільшення проекції площі крони є подібною для усіх варіантів. 
На варіантах із застосуванням гербіцидів, одночасним застосуванням гербіцидів і внесенням мінеральних добрив та внесенням мінеральних добрив за густоти насаджень 4000 і 1000 шт. га ${ }^{-1}$ середня площа крони становить $5,5 \ldots 5,8$ і $12,6 \ldots 13,1 \mathrm{~m}^{2}$, різниця між цими параметрами становить $22 \ldots 32$ і $54 . .58$ \% (таблиця).

Подібна тенденція зберігається і на варіантах досліду з проведенням механізованого догляду, але різниця $\epsilon$ дещо меншою. Так, за густоти насадження 4000-1000 шт. га $^{-1}$ середня площа крони становить $6,1-10,6$ м $^{2}$, різницю знаходимо в межах 21-42\%.

За однофакторним дисперсійним аналізом на $95 \%$ довірчому рівні достовірну різницю простежуємо між величинами площ проекцій крон усіх насаджень у межах варіантів, де $F_{\phi}=8,0 \ldots 108,7>F_{m(0,95)}=3,89$. Статистичні показники (стандартне відхилення, мода і медіана) площі проекції крони дещо також залежать від густоти насадження (див. таблицю).

Таблиця. Статистики ряду розподілу деяких параметрів крон дерев соснових культур з різною густотою

\begin{tabular}{|c|c|c|c|c|c|c|c|}
\hline \multirow{2}{*}{ № секції } & \multirow{2}{*}{$\begin{array}{c}\text { Початкова густо- } \\
\text { та, шт. } \cdot \text { га }^{-1}\end{array}$} & \multicolumn{4}{|c|}{ Середня площа проекції крони дерева, ${ }^{2}$} & \multirow{2}{*}{$\begin{array}{c}\text { Середня протяжність } \\
\text { крони, м }\end{array}$} & \multirow{2}{*}{$\begin{array}{c}\text { Зімкнутість пологу, } \\
\text { частка }\end{array}$} \\
\hline & & $M^{ \pm m}$ & $\sigma$ & Mo & $M e$ & & \\
\hline \multicolumn{8}{|c|}{ Варіант зі застосуванням гербіцидів } \\
\hline 1 & 4000 & $5,6^{ \pm 0,41}$ & $\pm 4,1$ & 3,9 & 4,5 & 4,7 & 0,80 \\
\hline 5 & 2000 & $8,2^{ \pm 0,65}$ & $\pm 6,8$ & 10,5 & 6,4 & 6,6 & 0,87 \\
\hline 9 & 1000 & $12,9^{ \pm 0,66}$ & $\pm 6,7$ & 7,3 & 11,1 & 6,4 & 0,88 \\
\hline \multicolumn{8}{|c|}{ Варіант з одночасним застосуванням гербіцидів та внесенням мінеральних добрив } \\
\hline 2 & 4000 & $5,5^{ \pm 0,32}$ & $\pm 3,3$ & 3,6 & 4,6 & 4,1 & 0,89 \\
\hline 6 & 2000 & $7,2^{ \pm 0,43}$ & $\pm 4,5$ & 2,9 & 6,0 & 5,2 & 0,83 \\
\hline 10 & 1000 & $13,1^{ \pm 0,66}$ & $\pm 6,7$ & 6,6 & 12,4 & 7,2 & 0,93 \\
\hline \multicolumn{8}{|c|}{ Варіант із внесенням мінеральних добрив } \\
\hline 3 & 4000 & $5,8^{ \pm 0,28}$ & $\pm 2,9$ & 7,3 & 5,4 & 5,1 & 0,88 \\
\hline 7 & 2000 & $7,4^{ \pm 0,33}$ & $\pm 3,3$ & 5,4 & 6,7 & 5,6 & 0,90 \\
\hline 11 & 1000 & $12,6^{ \pm 0,63}$ & $\pm 6,4$ & 7,7 & 11,1 & 8,1 & 0,85 \\
\hline \multicolumn{8}{|c|}{ Варіант зі проведенням механізованого догляду } \\
\hline 4 & 4000 & $6,1^{ \pm 0,35}$ & $\pm 3,6$ & 3,2 & 6,1 & 5,1 & 0,88 \\
\hline 8 & 2000 & $7,7^{ \pm 0,45}$ & $\pm 4,5$ & 7,5 & 7,4 & 5,0 & 0,87 \\
\hline 12 & 1000 & $10,6^{ \pm 0,48}$ & $\pm 4,8$ & 12,2 & 10,1 & 5,1 & 0,84 \\
\hline
\end{tabular}

Середня величина протяжності крони у значній частині варіантів свідчить про іiї залежність від початкової густоти (див. таблицю), однак відмінності цього показника є незначними. На варіанті із застосуванням гербіцидів між насадженнями з густотою 2000 і 1000 шт. га ${ }^{-1}$ різниця становить $3 \%$, а на варіанті з проведенням механізованого догляду між насадженнями 3 густотою 4000, 2000 і 1000 шт. га ${ }^{-1}$ різниця становить 0-2 \%. При цьому на варіантах з одночасним застосуванням гербіцидів і внесенням мінеральних добрив та внесенням мінеральних добрив між насадженнями з густотою 4000, 2000 і 1000 шт. $\cdot \mathrm{a}^{-1}$ різниця становить 9-21, 28-31 і 37$43 \%$ відповідно.

За допомогою площ проекцій крон встановили зімкнутість пологу в насадженнях із різною густотою. Зімкнутість пологу коливається у межах $0,8 \ldots 0,93$, різниця показників у межах варіантів становить 1-10\%. Встановити закономірності впливу початкової густоти на цей параметр насадження виявилось неможливим, оскільки незалежно від початкової густоти, крони дерев розростаються і заповнюють увесь вільний простір.

Висновок. Встановлено залежність середнього діаметра, площі проекції і протяжності крони соснових деревостанів від початкової густоти. Так, із зменшенням густоти від 4000 до 1000 шт. га ${ }^{-1}$ відбувається збільшення величини проекції площі та протяжності крони на 42-58 та 26-43 \% відповідно. Форма крон дерев у насадженнях із зменшенням густоти змінюється від овальної (сплюснута в ряді та витягнута в міжрядді) до майже округлої. Чіткої залежності між густотою насадження і зімкнутістю пологу не встановлено, здебільшого ці показники є близькими за значеннями. Різниця зімкнутості пологу між насадженнями коливається у межах 1-10\%.

\section{Перелік використаних джерел}

Anuchin, N. P. (1982). Forest taxation. Moscow: Lesnaia promyshlennost, $552 \mathrm{p}$. [In Russian].
Golovchanskiy, I. N., Belyy, G. D., \& Turchak, F. N. (1976). To develop a set of measures, technologies and recommendations for accelerated growing of wood in plantation-type forests near industrial centers - large consumers of wood. Research Report. Zhytomir: PALOS, 100 p. [In Russian].

Ilkiv, I. S. (1997). Estimation of form and parameters of crowns of trees. Methodical advice. Lviv: UkrDLTU, 26 p. [In Ukrainian].

Kuznetsov, A. N., Velichko, Ya. M., \& Starostin, V. A. (1986). Features of the formation of crowns of pine and spruce. Forestry, 12, 3031. [In Russian].

Mikhailova, T. A., \& Kalugina, O. V. (2012). The State of Scots Pine Forests in Barguzin Hollow. Russian Journal of Forest Science, 1, 29-35. [In Russian].

Pasternak, P. S. (Ed.). (1990). Forester reference book. Kiev: Urozhai, 296 p. [In Russian].

Razin, G. S., \& Rogozin, M. V. (2012). The theory of natural age dynamics of single-tier tree stands. Forestry, 3, 41-43. [In Russian].

Ryabokin, O. P. (1995). Structural and functional organization of pine plantations. Forest magazine, 2, 14-15. [In Ukrainian].

Sevko, O. A., \& Kotsan, V. V. (2012). Evaluation of the influence of spatial structure on the valuation indicators of tree stands using a digital model of the spatial distribution of trees. Proceedings of BSTU, 1, 57-59. [In Russian].

Shparyk, Yu. S. (2012). Characteristics of forests' stability and method for their identification. Scientific Bulletin of UNFU, 22(3), 58-63. [In Ukrainian]

SOU 02.02-37-476. (2006). Forest test plots. Method of laying. Kiev: Minahropolityky Ukrainy, 32 p. [In Ukrainian].

Tarnopilska, O. M. (2014). Dynamics of indices and relative productivity of crowns of artifical Scots pine stands in different density regimes in steppe zone. Forestry and Forest Melioration, 125, 53-63. [In Ukrainian].

Tsarenko, O. M., Zlobin, Ju. A., Sklyar, V. G., \& Panchenko, S. M. (2000). Computer methods in agriculture and biology. Sumy: Universytetska knyha, 203 p. [In Ukrainian].

Tsuryk, Ye. I. (2006). Taxation of the tree and its parts. Lviv: UNFU, 328 p. [In Ukrainian].

Yunovidov, A. P. (1951). The relationship between completeness, density and closure of forest canopy. Forestry, 10, 23-27. [In Russian]. 
O. V. Zhukovskyi

Poleski branch of Ukrainian Research Institute of Forestry and Agroforestry named after Vysotsky, Dovzhik, Ukraine

THE PARAMETERS OF CROWN TREES EXPERIMENTAL PINE PLANTATIONS,
WHICH ARE CREATED WITH VARIOUS DENSITY IN ZHYTOMIR POLYSSIA

The research has been conducted in Zhytomyr Polissya at stationary experiment № 1. Some parameters of tree crowns such as diameter, projection area and length of the crown and canopy closure of Scots pine (Pinus sylvestris L.) plantations with density 4000, 2000 and 1000 trees $\cdot h a^{-1}$ were analysed. Tree crown parameters were measured in the experiment according to common forestry and forest taxation methods. We have defined that with the density plantation 4000 trees $\cdot h a^{-1}$ average crown diameter ranges from 2.4 to $2.7 \mathrm{~m}$, with stand density 2000 trees $\cdot h a^{-1}-2.9-3.1 \mathrm{~m}$, and with stand density 1000 trees $\cdot h a^{-1}-3.6-4.0 \mathrm{~m}$, the difference between these values ranges from $9 \%$ to $40 \%$. We have also proved the true difference between the average tree crown diameters by single factor ANOVA at $95 \%$ confidence interval, where $F_{\phi}=7.82 \ldots 126.03>F_{m(0.95)}=3.89$. We have demonstrated that with plantation density 4000-2000 trees $h \mathrm{~h}^{-1}$ the form of crowns is oval (compressed in the line and elongated interstitial), where the plantation density 1000 trees $h a^{-1}$ - is almost round. There are some exceptions, i.e. plantations with the density 2000 and 1000 trees $\cdot \mathrm{ha}^{-1}$, where crowns are formed one-sided toward the southwest. We have also revealed, that the average crown projection area with plantation density 4000 trees $\cdot h a^{-1}$ is $5.5-6.1 \mathrm{~m}^{2}$, but with plantation density 1000 trees $\cdot h a^{-1}-10.6-13.1 \mathrm{~m}^{2}$, the difference between given parameters ranges from 42 to $58 \%$. We confirmed the difference between the values of tree crown projection area ANOVA, where $F_{\phi}=8.0 \ldots 108.7>F_{m(0.95)}=3.89$. We have diagnosed that crown length with plantation density 4000 trees $\cdot h a^{-1}$ is 4.1-5.1 m, with plantation density 2000 trees $\cdot h a^{-1} l$ it is $5.0-6.6 \mathrm{~m}$, and with plantation density 1000 trees $\cdot h a^{-1}$ it is $5.1-8.1 \mathrm{~m}$, the difference between the given values ranges from 9 to $43 \%$, in some cases it is small or absent. Therefore, the canopy closure of plantations with various densities is from 0.80 to 0.93 , the difference between the given values in the variants ranges from 1 to $10 \%$. We have made the conclusion that the density influences average diameter, projection area and length of tree crowns, whereas the influence of density on the canopy closure of the plantation is not found.

Keywords: Scots pine; crown diameter; crown projection area; crown length; canopy closure. 